NASA Technical Memorandum 83013

AIAA-83-0154

\title{
Effect of Broad Properties Fuel on Injector Performance in a Reverse Flow Combustor
}

Stephen M. Riddlebaugh and Carl T. Norgren

Lewis Research Center

Cleveland, Ohio

Prepared for the

Twenty-First Aerospace Sciences Conference

sponsored by the American Institute of

Aeronautics and Astronautics

Reno, Nevada, January 16-13, 1983 
EFFECT OF BROAD PROPERTIES FUEL ON INJECTOR

PERFORMANCE IN A REVERSE FLOW COMBUSTOR*

Stephen M. Riddlebaugh

and

Carl T. Norgren

National Aeronautics and Space Administration

Lewis Research Center

Cleveland, Ohio 44135

\section{Abstract}

The effect of fuel type on the performance of various fuel injectors was investigated in a reverse flow combustor. Combustor performance and emissions are documented for simplex pressureatomizing, spill flow, and airblast fuel injectors using a broad properties fuel and compared with performance using Jet $A$ fuel. Test conditions simulated a range of flight conditions including sea-level take-off, low and high altitude cruise, as well as a parametric evaluation of the effect of increased combustor loading. The baseline simplex injector produced higher emission levels with corresponding lower combustion efficiency with the broad properties fuel. There was little or no loss in performance by the two advanced concept injectors with the broad properties fuel. The airblast injector proved to be especially insensitive to fuel type.

\section{Introduction}

The effect of fuel type on the performance of various fuel injectors was investigated in a reverse flow combustor. Combustor performance and emissions were documented for simplex pressure atomizing, spill flow, and airblast fuel injectors using a broad properties fuel and compared with performance using Jet $A$ fuel.

As domestic sources of high quality crudes diminish, coupled with increased competition for the middie distillates, jet aviation fuel specifications may require modification or relaxation to ensure adequate supplies at reasonable cost. This is especially true if natural crudes are supplemented by crudes produced from alternate sources such as coal or oll shale, as well as middle distillates produced by cracking higher boiling point petroleum fractions.

Less stringent or broadened fuel properties could adversely affect aircraft engine performance and durability. For that reason there is a need for a data base of the effects of such fuels on current and future aircraft systems from which the technology to adopt these fuels can be developed. To this end NASA sponsored a fuels workshop which established an experimental referee broad specif $j-$ cation (ERBS) fuel to be used for this research.

Combustor programs are being conducted at the NASA Lewis Research Center to develop the technology to improve the reliability and performance of small gas turbine engines. Much of this effort is currently directed toward reverse flow combustors.

The reverse flow combustor's performance could be impacted by broad properties fuels in several

*For presentation at the 21 st AIAA Aerospace Sciences Meeting, Reno, Nevada, January 10-13, 1983. ways, some of which can be linked to injector performance. A large number of fuel injectors is required to effectively distribute the fuel around the primary zone annulus to provide satisfactory temperature patterns at the turbine. At the same time, mass flow rates are relatively low for the annulus size. Fuel flow requirements at low power and idle conditions are such that fuel flow per injector is extremely low. The physical sizes of the injector passages become so small that there is a serious possibility of fouling due to fuel contamination, gumming, or carbonizing. The small passages also make the injectors sensitive to fuel viscosity. Injector performance, in turn, affects emissions, pattern factor, carbon build-up, and in the case of fouling leading to streaking, liner durability, should the streak impact the liner wall.

In a previous investigation, $2,3,4$ the performance of various fuel-injection techniques was investigated in a small reverse flow combustor. Jet A fuel was used in that program. Performance and emission characteristics were measured for pressureatomizing, spill return, air blast, and air assist injectors and compared with simplex pressureatomizing injectors used as a baseline.

As a follow-on to that program, the two most promising injector designs and the baseline simplex injectors were evaluated at the same test conditions but with ERBS fuel. The combustor geometry was fixed and only the fuel injector types were varied. The three injector types investigated were simplex pressure-atomizing, spill return, and splash cone airblast. The effects of ERBS fuel on combustion efficiency, emissions, outlet temperature profile, and pattern factor were investigated for a simulated range of gas turbine engine conditions for a compression ratio of 16 . Data were obtained for emissions of unburned hydrocarbons, carbon monoxide, nitrogen oxides, and smoke number. The results were compared with results obtained with jet $A$ fuel.

\section{ERBS Fuel}

The experimental referee broad-specification (ERBS) fuel was defined by a jet engine hydrocarbon fuels workshop, sponsored by NASA and attended by representative of engine manufacturers, commercial airlines, and petroleum refiners. The purpose was to estabiish a laboratory standard referee fuel with which to conduct research and test programs, studying the impact of a broad properties fuel on aviation systems. The consensus of the workshop was that natural petroleum crudes would continue to be the primary source of aviation jet fuel through this century. However, increasing competition for middle distillate products would result in increased production of middle distillate fractions by cracking higher boiling point materials. The higher aromatics content of cracked products would require extensive refining to meet current jet-fuel spec1- 
fications. Adoption of a broad properties fuel could heip ensure adequate supplies at reasonable cost.

Table 1 compares some of the properties of ERBS fuel with Jet $A$ and $D i e s e l$ No. 2 properties. It should be noted that the ERBS fuel properties listed were obtained by chemical analysis of a sample of the ERBS blend used in this test. The ERBS specifications for such properties as aromatics content were established as a range and can vary from batch to batch. In the case of aromatics content, a maximum was set by the workshop at 35 volumetric percent. On the other hand, the properties for the Jet $A$ and Diesel No. 2 fuels are typical values found in the interature.

\section{Apparatus Test Facility}

The test combustor was mounted in the closedduct facility shown schematically in figure 1 . The laboratory air supply can maintain airflow rates up to $15 \mathrm{~kg} / \mathrm{sec}$ at pressure levels up to $3000 \mathrm{kPa}$. Tests were conducted up to an inlet-air pressure of $1600 \mathrm{kPa}$. For these tests combustion air drawn from the laboratory high-pressure supply was indirectly heated to a temperature of about $720 \mathrm{~K}$ in a counterflow tube heat exchanger. The temperature of the air flowing out of the heat exchanger was automatically controlled by mixing the heated air with varying amounts of cold bypassed air. Airflow through the heat exchanger and bypass flow system and the total pressure of the combustor inlet airflow were regulated by remotely controlled valves.

\section{Combustor}

A cross-section of the reverse flow combustor used in this investigation is shown in figure 2(a). An isometric sketch of it is shown in figure $2(b)$. The combustor is a full scale experimental NASA design with a maximum diameter of $38.5 \mathrm{~cm}$. The design stresses versatility so that modification or replacement of the swirlers, fuel injectors, faceplate liner, and turbine sections can be accomplished. The design liner pressure loss is 1.5 percent and the diffuser dump loss is 0.24 percent. The configuration used in this test had 18 fuel injector locations. The airflow distribution and hole sizes are shown in Table 2.

The combustor instrumentation stations are shown in figure 3. Five total pressure probes, two static pressure taps, and five chromel-alumel thermocouples are located at Station 2 to measure the inlet temperature and pressure. At Station 3 a series of 18 total pressure probes are installed to determine the inlet-air prof lle and the extent of any flow disturbance behind the struts supporting the centerbody diffuser. At Station 4 six pitot-static probes are positioned in the cold air passages between the combustor liner and research housing to determine air velocity and distribution. The combustor exit plane, Station 5 , contains 4 evenly spaced gas sample probes, 12 temperature measuring rakes with 5 thermocouples in each rake, 5 total pressure probes, and 1 static pressure tap.

\section{Fuel injectors}

The three fuel injector types used in this program were selected from a group of seven injector types surveyed in a previous program using jet $A$ fue $1.2,3$ A small commercially available pressure atomizing injector used for the baseline study in that program served the same purpose in this program. The other two injectors were originally developed in an Army sponsored program to assist the development of small-scale high performance combustors and performed quite well with Jet $A$ fuel.

Fuel injector characteristics for the three injectors are listed in Table 3 for Jet $A$ and Diesel No. 2 fuel.

Simplex Pressure Atomizing Injector. This injector was selected to establish the reference base and to determine the operational limits and emission production of the combustor configuration. The commercial injector selected has a body $1.1 \mathrm{~cm}$ long and $0.8 \mathrm{~cm}$ diameter with an NEF-32-3A thread. The injector passages were sized to provide most of the fuel flow range required for the simulated test conditions as indicated in Table 4 and discussed in the PROCEDURE section.

For Jet $A$ fuel the flow number was 4.8 and the spray angle $75^{\circ}$. The Sauter Mean Diameter (SMD) was estimated to be $100 \mu \mathrm{m}$.

With Jet $A$ fuel the simplex injectors performed well over a limited range. However, blowout was encountered at low power conditions and idle was not achreved with 18 injectors.

Splll Flow Return Injector. The spill flow return injector is a pressure atomizing type which uses spin slots to achieve a tangential fuel velocity in the single discharge orifice. It is in effect a variable area injector due to the incorporation of a spill port which allows fuel to be returned from the spin chamber to the fuel tank. This spill flow reduces the apparent area of the spin slots so that the fuel supply pressure can be maintained high enough for good atomization and spray characteris$t$ ics. The cross-sectional view of the injector is shown in figure $4(a)$.

With the splli valve closed (no return flow) the flow number was 3.1 for Jet $A$ fuel; with the spill valve fully open, the flow number decreased to .75 . The SMD was approximately $100 \mu \mathrm{m}$ throughout most of the flow range and decreased to $75 \mu \mathrm{m}$ at the maximum flow point. The spray angle was a welldefined hollow cone with an included angle of about $90^{\circ}$ which increased to $120^{\circ}$ as the spill-flow port was opened. The increase in cone angle with spillflow is expected. The patternator readings were relatively uniform over the splll-flow range, indicating a uniform spray pattern. However, when the spill-flow was reduced to zero the pattern deteriorated.

With Diesel No. 2 fuel the SMD increased by about $20 \mu \mathrm{m}$ over the Jet $A$ values. The patternator readings were slightly improved. This type of injector had relatively large passages and was fairly insensitive to fuel-viscosity changes.

With Jet $A$ fuel the injector performed well over the entire range of test conditions. A 91 percent combustion efficrency was obtained at idle with 18 injectors. The injector produced a relatively smokey exhaust. 3 
Splash Cone Air Blast Injector. The injector is an airblast type which uses simple orifices to distribute low pressure fuel into an air stream with subsequent atomization by a blast of swirling air. The splash cone consists of a concave surface around a central fuel tube. The tube has four radial jets impinging on the concave surface to deliver a uniform sheet of fuel into the airstream. The crosssectional view of the injector is shown in figure $4(b)$.

The flow number of the splash cone injector is 6.4 with Jet $A$ fuel (Table 3 ). Atomization characteristics were very difficult to determine except by direct observation. The cone angle ranged up to $200^{\circ}$ over most of the operating range with four dense sprays located radially from each orifice. Thus all determinations of SMD, cone angle, and spray pattern were distorted. Mean drop size was $160 \mu \mathrm{m}+20$ with patternator readings from 70 to 80 percent, indicative of a very distorted spray pattern. Performance with a high viscosity fuel (Diesel No. 2) was almost identical to Jet A performance. Atomization and spray pattern deteriorated badly as viscosity approached that of water, with SMD increasing to $350 \mu \mathrm{m}$ and patternator readings deviating by as much as 100 percent. (When flowed with water in a visual observation test the injector produced four radial streams of liquid.)

In the previous program with Jet $A$ fuel, 3 , the splash-cone injector performed well over a limited range of conditions; however, blowout was encountered at low power conditions. Pattern factors were very low (0.18 at cruise) and the injectors produced low smoke levels (a smoke number less than 2 at cruise). This performance was better than anticipated based on patternator tests. The patternator testing was apparently done with insufficient swirler air for proper airblast atomization. Each injector location in the combustor liner had a fixed swirler, so when these injectors were installed there were two concentric swirlers at each injection point (one swirler bullt into the injector and one bullt into the liner).

\section{Procedure}

\section{Test Conditions}

The experimental reverse flow combustor was operated at test conditions based on a gas turbine engine cycle with a compressor pressure ratio of 16. A tabulation of the test conditions simulated in this study are shown in Table 4.

Data were obtained at combustor inlet conditions simulating sea level take-off, cruise, and idle. Data were obtained over a range of fuel-air ratios from about 0.008 to 0.016 . However, because of thermocouple limitations, the overall fuel-air ratio was limited to approximately 0.014 at sea-level takeoff. At the idle condition the fuel-air ratio was 0.008 . The combustor was operated with a parametric variation of reference velocity at sea-level and cruise $(7$ and $9 \mathrm{~m} / \mathrm{s})$, in addition to the reference velocity of $5 \mathrm{~m} / \mathrm{s}$. The reference velocity quoted is based on the assumption of unidirectional total mass flow and the maximum cross-sectional area of the housing prior to the reverse turn as shown in figure 2(a). The combustor was also operated at simulated reduced power at a constant fuel-air ratio of 0.014 . For the reduced power conditions a pressure level lower than cruise was selected and the corresponding inlet temperature was calculated using a compressor efficiency of 80 percent. Also presented in Table 4 are the simulated compressor pressure ratios. These ratios as presented are referenced to sea-level pressure. The test program was conducted using ERBS fuel.

\section{Emission Measurements}

Exhaust gas samples were obtained according to the procedures recommended in 5 and 6 . Exhaust gases were withdrawn through four water-cooled probes mounted approximately in the stator plane and in the center of the exhaust duct at station 5 (see fig. 3). Concentrations of oxides of nitrogen $\left(\mathrm{NO}_{\mathrm{X}}\right)$, carbon monoxide $(\mathrm{CO})$, and unburned hydrocarbons (UHC) were determined with the gas-analysis system described in 7. The gas-sample temperature was held at approximately $423 \mathrm{~K}$ in the electrically heated sampling line. Most of the gas sample entered the analyzer oven, while the excess flow was bypassed to the exhaust system. To prevent fuel accumulation in the sample line, a nitrogen purge was used just before and during combustor ignition. After passing through the analyzer oven, concentrations of $\mathrm{NO}_{x}, \mathrm{CO}, \mathrm{CO}_{2}$, and hydrocarbons were measured by the chemlluminescence, nond ispersed-in-frared, and flame-ionization methods, respectively.

Gas samples used to determine oxides of $\mathrm{NO}_{\mathrm{x}}$, $\mathrm{CO}_{2}$, and $\mathrm{CO}$ were passed through a refrigerated dryer and analyzed on a dry basis. Readings of $\mathrm{N} 0_{x}$ of nitrogen and $\mathrm{CO}$ were corrected so that they could be reported on a wet basis, as were those for unburned hydrocarbons.

Fuel-air ratios calculated from a carbon balance agreed to within 10 percent with values obtained from fuel flow and airflow measurements. The combustion efficiency data presented in this report were based on stoichiometry determined by gas analysis.

\section{Results and Discussion}

The following data were obtained using the reverse flow combustor to investigate the effect of a broad properties fuel (ERBS fuel) on combustor performance and emissions with three different injector types. Data were obtained for simulated in let conditions typical of a 16 to 1 pressure ratio turbine engine. The simulated flight and idle conditions are tabulated in Table 4. The out let temperature level was limited to $1350 \mathrm{~K}$ because of instrumentation constraints. The combustor was operated with 18 evenly spaced fuel injectors. Data were compared with injector performance data using Jet $A$ fuel, previously presented in 2 and.3. The performance and emissions data are presented in figures 5 to 7 .

Simplex Injectors. Performance data are presented in figures 5(a) to $(\mathrm{g})$. Previously reported data are presented as broken lines in these figures.

There was a loss of combustor efficiency averaging one percent over the operating $r$ ange from sea-level take-off to altitude cruise (fig. 5(a)). At the highest power conditions, loss in overall efficiency was very small. At lower power condi- 
tions the loss in efficiency was greater; this probably reflected injector performance deterioration as the fuel flow was reduced as well as sensitivity to increased fuel viscosity. Idle conditions were unobtainable with either ERBS or Jet $A$ fuel with 18 simplex injectors. The combustor blew out at a higher power condition with the ERBS fuel than with Jet $A$ fuel.

As seen in figure $5(b)$, the average radial temperature profile at the combustor exit station was attenuated when using ERBS fuel. The shapes of the profiles for both fuels were similar. Pattern factors were likewise simllar with both fuels (fig. 5(c)). However as combustor inlet pressure increased, the pattern factor with ERBS fuel leveled off at 0.29 while the pattern factor with Jet $A$ continued to decrease.

At low-power conditions (combustor inlet pressures below $900 \mathrm{kPa}$ ), $\mathrm{NO}_{\mathrm{x}}$ emissions were the same for both fuels (fig. 5(d)). At higher pressures there was a dramatic decrease in NOX levels produced with the ERBS fuel. The lower N0 levels are consistent with the lower peak temperatures as ind lcated in figure $5(b)$.

There was a marked increase in co emissions with ERBS fuel. As shown in figure $5(e)$, an average increase in CO emission index of 20 was produced over most of the operating range. However there was no corresponding increase in hydrocarbon emissions, as seen in figure $5(\mathrm{f})$.

At lower combustor inlet pressures the ERBS and Jet $A$ fuels produced similar amounts of smoke (fig. $5(\mathrm{~g})$ ). As pressures increased, the ERBS fuel produced increasingly more smoke until at the sealevel takeoff condition (inlet pressure of 1600 $\mathrm{kPa}$ ) an increase in smoke number of 20 over the Jet A smoke level was measured. Also, at the high power conditions the Jet $A$ smoke production leveled off at a smoke number of 20 , while the ERBS fuel-produced smoke continued to increase at a high rate.

The attenuated temperature profile, reduced NOx, higher CO and smoke, and slight reduction in overall efficiency indicated that the combustion process with ERBS fuel was not as complete as with Jet $A$ fuel. Increasing residence time in the combustor might improve emissions and performance; increasing reference velocity (lowering residence time) resulted in a deterioration in performance.

Spill-Flow Return Injector. Figure 6(a) compares overall combustion efficiencies produced with ERBS fuel and Jet $A$ fuel. ERBS fuel data for the injector operating in both spill and non-spill modes are presented; only spill mode data are presented for Jet $A$ fuel in the figure. At combustor pressures corresponding to cruise conditions, both fuels produced essentially identical efficiencies. At idle conditions ( $400 \mathrm{kPa}$ inlet pressure) the ERBS fuel produced efficiencies of 89 percent with the spill port closed and 94 percent with the sp 111 port open; the efficiency with Jet $A$ fuel at this condition was about one percent higner. At the simulated cruise conditions, the fuel flow rate was such that spill-returning excess flow to the fuel tank did not improve performance.

As with the simplex injectors, the splli-return injectors produced a slight attenuation of the aver- age radial temperature profile at the combustor exit with ERBS fuel (fig. 6 (b)). Over most of the operating range, temperaiure pattern factors were identical for the two fuels, as seen in figure $6(\mathrm{c})$. However as the simulated idle condition was approached, the pattern factor with ERBS fuel showed a marked deterioration, while the pattern factor with Jet $A$ fuel remained almost constant throughout the entire range of conditions.

Oxides of nitrogen levels produced with the two fuels are compared in figure 6(d). The ERBS fuel produced slightly more $\mathrm{NO}_{\mathrm{x}}$ than the Jet $\mathrm{A}$ fuel, with the greatest increases occuring at simulated low-power conditions.

Carbon monoxide and UHC emission levels for the two fuels were about the same at simulated cruise conditions (fig. 6(e) and 6(f), respectively).

Low-power emissions were higher with the ERBS fuel. At the simulated idle condition both fuels produced high levels of $\mathrm{C} 0$ and unburned hydrocarbons with this injector.

As shown in figure $6(\mathrm{~g})$, smoke levels were similar for both fuels at low-power conditions but were much higher for ERBS fuel at cruise conditions. Increasing the reference velocity caused a degradation of pattern factor and increased smoke but reduced $\mathrm{NO}_{\mathrm{X}}$ emissions (Table 5).

Splash-Cone Airblast Injector. In calibration tests performed by the Lee Company, the results of which are summarized in Table 3 , this injector gave almost identical performance with a test fluid simulating Jet $A$ fuel and Diesel 2 fuel. It was anticipated that its performance with ERBS fuel would be very close to its performance with Jet A fuel, as reported in 3.

Figure $7(a)$ compares combustion efficiency of the injector with the different fuels. At simulated cruise and high-power conditions performance was identical. With 18 injectors, idle conditions were attainable with ERBS fuel but not with Jet $A$ fuel.

As seen figure $7(b)$, the average radial temperature profile at the combustor exit was only slightly aitered by changing from Jet $A$ to ERBS fuel. The location of the hignest temperatures shifted radially outward when burning ERBS fuel, producing a more symmetrical profile. The pattern factor was identical with both fuels for the simulated highpower/cruise conditions (fig. $7(\mathrm{c})$ ). With Jet A fuel, pattern factor remained fairly constant throughout the operating range unt il the blow-out condition was approached, at which point pattern factor suddenly deteriorated. With the ERBS fuel, the pattern factor began to deteriorate at a higher power condition but the change rate was more gradual.

$0 \times$ ides of nitrogen emission were slightly increased when ERBS fuel was used (fig. 7(c)). This could reflect the anticipated hotter flame temperatures resulting from reauced hydrogen content in the fuel. Carbon monoxide and UHC emissions were identical with the two fuels, as seen in figures $7(\mathrm{e})$ and $7(\mathrm{f})$.

Figure $7(\mathrm{~g})$ compares smoke emissions produced by the splash-cone airblast injector with Jet $A$ and ERBS fuel. At simulated high-power conoitions both 
fuels produced the same amount of smoke. At lower power conditions the ERBS fuel was smokier, although smoke levels were still the lowest produced by the three injector types investigated.

As seen in Table 5, increasing reference velocity resulted in a deterioration in pattern factor, reduced $\mathrm{NO}_{\mathrm{X}}$ emissions, but higher smoke levels when ERBS fuel was used. This indicates a less complete combustion process. Performance with Jet A fuel was less sensitive to reference velocity changes.

Carbon Formation. All three injector types experienced carbon buildup on the injector tip with Jet $A$ fuel. The simplex injector fuel struts were modified to direct some primary zone air across the injector tips. The modification eliminated all carbon deposition except for some minor sooting.

The spill-flow return injectors buit up a massive, hard carbon deposit on the plug tip with Jet A fuel. The worst deposits were of a size about equal to half the combustor annulus height. One of these deposits is pictured in figure 8 . It was felt that the carbon buildup problem was aggravated when the injector was operated in Splll mode at low-power conditions (a large portion of incoming fuel being returned to the tank). This excess flow caused the injector tip to run cold.

As with the simplex injectors, the spill-flow return injector fuel struts were modified to provide an air "wash across the injector tip. The modifications were made before running with ERBS fuel and were essentially the same as the simplex fuel-strut modifications. The modifications consisted of four shallow longitudinal grooves milled in the fuelstrut barrel to duct air inside passed the swirlers and an air cap that directed this air across the injector tip. The left-hand and center injectors in figure 8 show this modification. The picture was taken after they were run with ERBS fuel but before they were cleaned. The center injector shows some burning of the air cap that probably occurred during spili-mode operation. During spill-miode. operation the spray cone angle opened up to $120^{\circ}$ and the spray contacted the air cap on this strut.

The splash-cone airblast injectors experienced carbon bulld-up with both Jet $A$ and ERBS fuel. The deposits were similar but the ERBS fuel deposits were thicker and more robust. Typical ERBS-produced deposits are pictured in figure 9. Portions of the deposits were broken off when the injector was removed from the test rig.

The carbon deposits were of two similar forms: either a thin circular deposit or distinct lobes growing from the base of the injector caps. The lobes grew radially outward from the fuel exit points of the injector. It was felt that these deposits could be prevented by a redesign of the injector.

The fact that the carbon deposits on the splashcone caps grew at right angles to the injector axis indicates that the included cone angle of the spray approached $180^{\circ}$. Additional swirler air to bend the spray cone downstream may be desirable for several reasons. One is that the increased airblast might prevent the carbon deposits from forming.
Another is that the fuel droplets could impinge on the liner walls with serious consequences. It should be noted that reverse flow combustor designs have inherently low pressure drops across their liner walls ( 1.5 percent in the design used in this program). Thus this combustor configuration has less pressure avallable for the airblast effect. The parametric variation data indicate that the splash-cone injector performance improved with increased loading.

No carbon deposits were observed on the combustor liner except for some minor sooting of the swirlers. The spill-flow return injector carbon plug, shown in figure 8 , caused the fuel to be deflected against the inner liner wall, resulting in a small hole being burned through the wall in the region of the primary zone penetration holes. No liner damage definitely attributable to the splashcone injector carbon deposits was observed during this test.

\section{Summary of Results}

A reverse flow combustor suitable for a small gas turbine engine was used to evaluate the effects of fuel type on combustor performance and emissions. ERBS fuel was used for the test and results compared with previous tests using Jet $A$ fuel. Data were obtained for simplex pressure-atomizing, spill return, and splash-cone airblast injectors at pressure and inlet air temperature levels corresponding to idle, altitude, cruise, and sea-level takeoff conditions for a 16 pressure ratio engine. Outlet temperature was limited to about $1350 \mathrm{~K}$ because of the instrumentation.

For all three injector types there was a slight loss in combustion efficiency at low-power conditions but no appreciable losses at high-power conditions. Emission performance was mixed, while smoke production was generally greater with the ERBS fuel than with Jet $A$ fuel.

Specific results for each injector type were as follows:

Simplex pressure atomizing injectors. The only significant changes in performance were in emissions levels. With ERBS fuel, NOx emission were significantly lower while emissions were much higher compared with emissions produced with Jet $A$ fuel. At high-power conditions, considerably more smoke was produced with the ERBS fuel. At all test conditions there was a slight loss in combustion efficrency with ERBS fuel.

Spill-return injectors. At low-power conditions there was some deterioration in performance when ERBS fuel was used, although some of this loss could be recovered by optimizing the spill-flow fuel scheduling. Operating the injectors in splll mode was more beneficial at low-power settings than at high power. At high-power conditions the ERBS fuel produced considerably more smoke.

Splash-cone airblast injectors. This injector type gave neariy identical performance with Jet $A$ and ERBS fuel. One significant difference was that idle conditions were obtainable with ERBS fuel, while blow-out occured before idle conditions were achieved with jet $A$ fuel. Also, more smoke was 
produced at low-power condition with ERBS fuel but not at high-power conditions.

Carbon formation. All three injector types experienced serious carbon build-up with Jet $A$ fuel but the simplex and splll return injector tips received minor modification that eliminated this problem. The splash-cone injectors were not modified and experienced a greater carbon bulld-up with ERBS fuel than with Jet $A$. Splash-cone-injector performance was not noticeably effected by the deposits that accumulated during the test which was of short duration. It was felt that the carbon bulldup problems could be el iminated by a redesign of the injector.

Overall it appears that advanced fuel injector designs will be able to give satisfactory atomization performance with broad properties fuels. The spill-return injector's relatively large passage sizes (compared with fixed orifice pressureatomizing injectors size for the same flow rate) make it less senistive to changes in fuel viscosity. The performance of the airblast injector investigated in this test indicates that airblast designs in general will be insensitive to changes in fuel properties.

\section{REFERENCES}

1. Longwe11, J. P., ed., "Jet Aircraft Hydrocarbon Fuels Technology," NASA CP-2033, 1978.
2. Norgren, C. T., Mularz, E. J., and Riddlebaugh, S. M., "Reverse-Flow Combustor for Small Gas Turbines with Pressure-Atomizing Fuel Injectors. " NASA TP-1260, Aug. 1978.

3. Norgren, C. T. and Riddlebaugh, S. M., "Effect of Fuel Injector Type on Performance and Emission of Reversef low Combustor." NASA TP-1945, Dec. 1981.

4. Norgren, C. T. and Riddlebaugh, S. M., "Small Gas-Turbine Combuster Study - Fuel Injector Evaluation," NASA TM-82641, 1981.

5. "Control of Air Pollution from Aircraft and Aircraft Engines - Emission Standards and Test Procedures for Aircraft," "Federal Register, Vol. 38 , No. 136, Pt. 2, JuTy 17, 1973, pp. $19088-19103$.

6. "Procedure for the Continuous Sampling and Measurement of Gaseous Emissions from Aircraft Turbine Engınes," ' Aerospace Recommended Practıce 1256 A, SAE, 1980 .

7. Ingebo, R. D. and Norgren, C. T., "High-Pressure Combustor Exhaust Emissions with Improved AirAtomizing and Conventional Pressure-Atomizing Fuel Nozzles," NASA TN D-7154, Feb. 1973.

Table 1 - Experimental referee broad specification (ERBS) fuel properties compared to jet $A$ and diesel 2 fueis

\begin{tabular}{|c|c|c|c|}
\hline Property & ERBS & $\begin{array}{l}\text { Fuel } \\
\text { jet } A\end{array}$ & Diesel 2 \\
\hline $\begin{array}{l}\text { Bolling Point, } K(R): \\
\text { initial } \\
\text { final }\end{array}$ & $\begin{array}{r}442(795) \\
625(1126)\end{array}$ & $\begin{array}{l}442 \\
544\end{array}\left(\begin{array}{l}795 \\
980\end{array}\right)$ & $\begin{array}{r}450(810) \\
621(1118)\end{array}$ \\
\hline $\begin{array}{l}\text { Distillation point } \\
(10 x), K(R)\end{array}$ & $466(840)$ & $460(829)$ & $490(882)$ \\
\hline $\begin{array}{l}\text { Lower heating value } \\
\mathrm{J} / \mathrm{g}(\mathrm{Btu} / \mathrm{Ib})\end{array}$ & $41900(18170)$ & $43000(18600)$ & $42600(18464)$ \\
\hline $\begin{array}{l}\text { Hydrogen - carbon } \\
\text { rat } 10\end{array}$ & 0.148 & 0.160 & 0.150 \\
\hline Aranatics, vol. $\$$ & 27.46 & 16.8 & 30.5 \\
\hline $\begin{array}{l}V_{1 s \operatorname{scos} 1 t y} \text { at } 311 \mathrm{~K} \\
\left(100^{\circ} \mathrm{F}\right) \mathrm{M}^{2} / \mathrm{sec}(\mathrm{cS})\end{array}$ & $1.64 \times 10^{-6}(1.64)$ & $1.52 \times 10^{-6}(1.52)$ & $3.10 \times 10^{-6}(3.10)$ \\
\hline Freeze points, I ("F) & $44(-20)$ & $228(-49)$ & 258 (5) (pour point) \\
\hline $\begin{array}{l}\text { Specif ic gravity } \\
\text { at } 288 \mathrm{~K}\left(60^{\circ} \mathrm{F}\right)\end{array}$ & 0.840 & 0.813 & 0.853 \\
\hline
\end{tabular}

\begin{tabular}{|c|c|c|c|}
\hline $\begin{array}{l}\text { Air } \\
\text { entry }\end{array}$ & $\begin{array}{l}\text { Type of } \\
\text { entry }\end{array}$ & $\begin{array}{l}\text { Percent of } \\
\text { total mass } \\
\text { flow }\end{array}$ & Coments \\
\hline Faceplate & Swirler & 24.8 & $\begin{array}{l}2.54 \mathrm{~cm} \text { from firewall, } 36 \text { holes } \\
\text { outer wall and } 36 \text { holes inner wall }\end{array}$ \\
\hline Primary & Primary holes & 18.6 & $\begin{array}{l}5.72 \text { col from firewall, } 36 \text { holes } \\
\text { outer wall and } 36 \text { holes inner wall }\end{array}$ \\
\hline Dilution & Drlution holes & 24.1 & $\ldots$ \\
\hline $\begin{array}{l}\text { Concentric } \\
\text { around fuel } \\
\text { injector }\end{array}$ & Annulus & 3.17 & \\
\hline Liner cooling & Fila cooling & 13.21 & 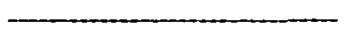 \\
\hline Outer $180^{\circ}$ & Film cooling & 13.08 & \\
\hline Inner $180^{\circ}$ & Filu cooling & 3.02 & \\
\hline
\end{tabular}


Table 3 - Fuel injector characteristics for jet a fuel (O)esel No. 2 in Brackets)

\begin{tabular}{|c|c|c|c|c|c|c|c|c|}
\hline \multirow[t]{2}{*}{$\begin{array}{l}\text { Fuel } \\
\text { injector }\end{array}$} & \multirow{2}{*}{$\begin{array}{c}\text { F low } \\
\text { number } \\
w f / \sqrt{\Delta_{0}}\end{array}$} & \multirow{2}{*}{$\begin{array}{l}\text { Drop } \\
\text { Size } \\
\text { SMD }\end{array}$} & \multicolumn{6}{|c|}{$\begin{array}{l}\text { Patternation percent } \\
\text { deviation }\end{array}$} \\
\hline & & & \multicolumn{6}{|c|}{ sector } \\
\hline & & & 1 & 2 & 3 & 4 & 5 & 6 \\
\hline Simplex & 4.8 & $100(110) *$ & & & & & & \\
\hline $\begin{array}{l}\text { Splll } \\
\text { return }\end{array}$ & $3.1(3.3)$ & $\begin{array}{c}75-100 \\
(90-120)\end{array}$ & $\begin{array}{r}10 \\
(2)\end{array}$ & $\stackrel{7}{(1)}$ & $\begin{array}{c}0 \\
(0)\end{array}$ & $\stackrel{2}{(7)}$ & $\stackrel{2}{(11)}$ & $\begin{array}{c}8 \\
(10)\end{array}$ \\
\hline $\begin{array}{l}\text { Splash } \\
\text { cone }\end{array}$ & $6.4(6.5)$ & $\begin{array}{c}160+20 \\
(160+20)\end{array}$ & $\begin{array}{c}20 \\
(20)\end{array}$ & $\begin{array}{c}0 \\
(0)\end{array}$ & $\begin{array}{l}60 \\
(70)\end{array}$ & $\begin{array}{r}40 \\
(90)\end{array}$ & $\begin{array}{c}65 \\
(60)\end{array}$ & $\begin{array}{c}65 \\
(35)\end{array}$ \\
\hline
\end{tabular}
Patternation and SMO measurements described in reference 3.

Table 4 - Reverse-f low combustor test conditions

\begin{tabular}{|c|c|c|c|c|c|c|c|}
\hline $\begin{array}{c}\text { Test } \\
\text { condition }\end{array}$ & $f / \mathrm{a}$ & $\begin{array}{l}\text { Total } \\
\text { airf low, } \\
\mathrm{kg} / \mathrm{s}\end{array}$ & $\begin{array}{l}\text { Inlet } \\
\text { pressure, } \\
\mathrm{kPa}\end{array}$ & $\begin{array}{l}\text { Inlet } \\
\text { temp., } \\
\mathrm{K}\end{array}$ & $\begin{array}{l}\text { Reference } \\
\text { velocity, } \\
\mathrm{m} / \mathrm{s}\end{array}$ & $\begin{array}{l}\text { Simulated } \\
\text { pressure } \\
\text { ratio }\end{array}$ & Comnents \\
\hline $\mathrm{A}$ & 0.014 & 2.7 & 1014 & 686 & 5.5 & 101 & $\begin{array}{l}\text { High alt } \\
\text { cruise } \\
\text { Low alt } \\
\text { cruise } \\
\text { Sea leve1 } \\
\text { take-0ff }\end{array}$ \\
\hline $\mathrm{C}$ & .014 & 3.05 & 1358 & 703 & 5.5 & 13.41 \\
\hline
\end{tabular}

Table 5 - Effect of parametric variation of combustor reference velocity on pattern factor, emissions of nitrogen oxides, and smoke number at a nominal

\begin{tabular}{|c|c|c|c|c|c|c|}
\hline Fuel injector & $\begin{array}{l}\text { Reference * } \\
\text { velocity } \\
\mathbb{m} / \mathrm{s}\end{array}$ & $\begin{array}{c}\text { Inlet } \\
\text { pressure, } \\
\mathrm{kPa}\end{array}$ & $\begin{array}{l}\text { Inlet } \\
\text { temp., } \\
K\end{array}$ & $\begin{array}{l}\text { Pattern } \\
\text { factor }\end{array}$ & $\begin{array}{l}\text { NOx } \\
\text { emission } \\
\text { index, } \\
g / \mathrm{kg} \text { fuel }\end{array}$ & $\begin{array}{l}\text { Smoke } \\
\text { number }\end{array}$ \\
\hline $\begin{array}{l}\text { Sumplex } \\
\text { pressure } \\
\text { atomizing }\end{array}$ & $\begin{array}{l}5.5 \\
7.3 \\
91\end{array}$ & 1390 & 709 & $\begin{array}{rr}0.30 & (0.24) \\
.29 & .22) \\
.28 & .41\}\end{array}$ & $\begin{array}{r}9.2(14.1) \\
10.3(13.2) \\
9.5(12.4)\end{array}$ & $\begin{array}{l}31.4(17.0) \\
26.0 \\
31.2\end{array}(16.0)$ \\
\hline $\begin{array}{l}\text { Spill } \\
\text { return }\end{array}$ & $\begin{array}{l}5.5 \\
7.3 \\
9.1\end{array}$ & & & $\begin{array}{l}.26 \\
.24 \\
.30 \\
.30 \\
(.23) \\
(.29)\end{array}$ & $\begin{array}{l}15.8(16.8) \\
13.0(13.9) \\
11.3(10.7)\end{array}$ & $\begin{array}{lll}44 & 5 & (27.5) \\
45.3 & (31.0) \\
48.8 & (24.0)\end{array}$ \\
\hline $\begin{array}{l}\text { Splash cone } \\
\text { airblast }\end{array}$ & $\begin{array}{l}5.5 \\
7.3 \\
9.1\end{array}$ & $\downarrow$ & 690 & 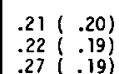 & $\begin{array}{l}13.3(14.1) \\
120(107) \\
11.7(9.8)\end{array}$ & 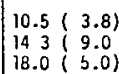 \\
\hline
\end{tabular}

* Reference velocity based on maximum cross-sectional area of housing (see fig. 2). 


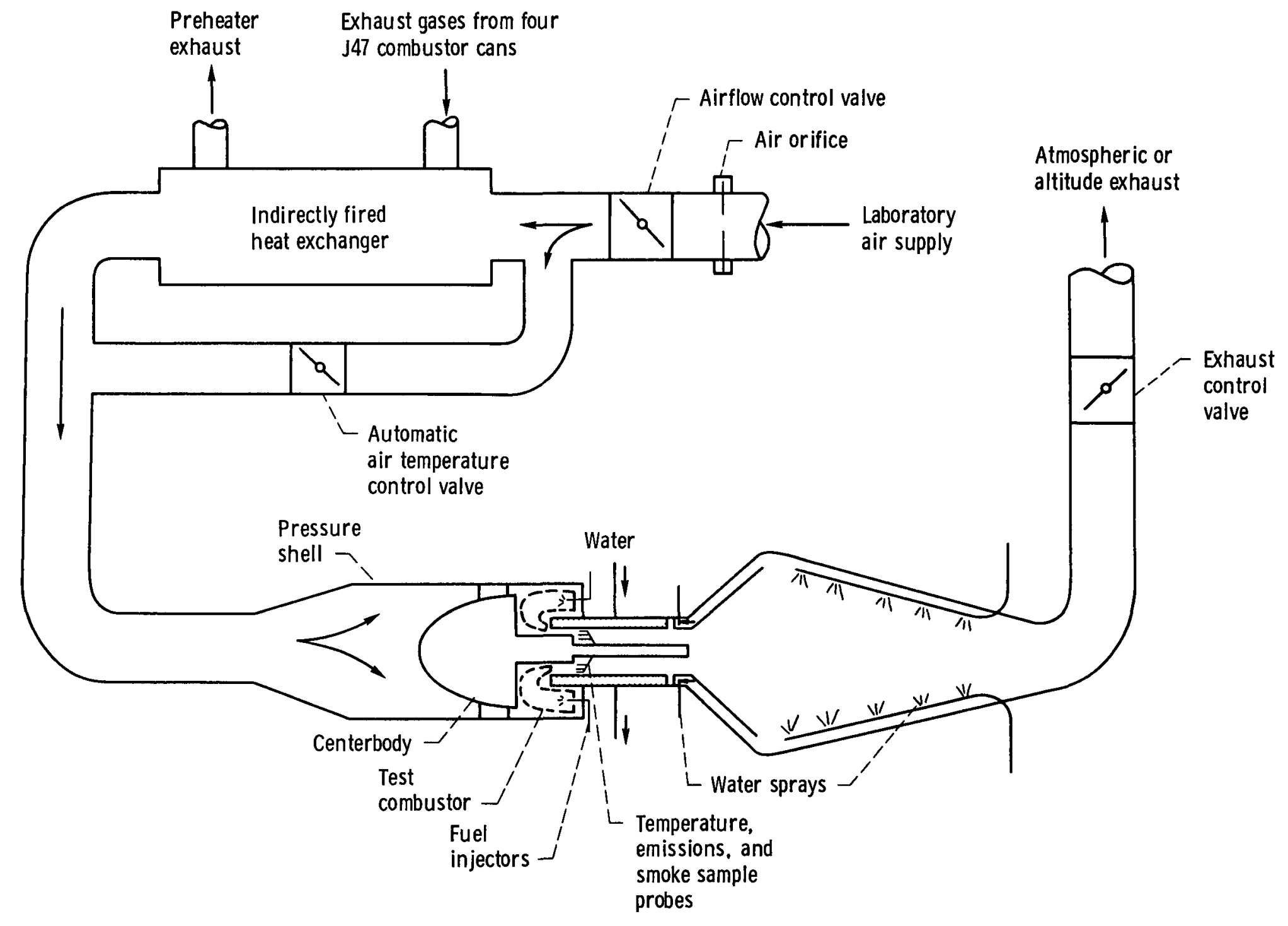

Figure 1. - Schematic of test facility. 


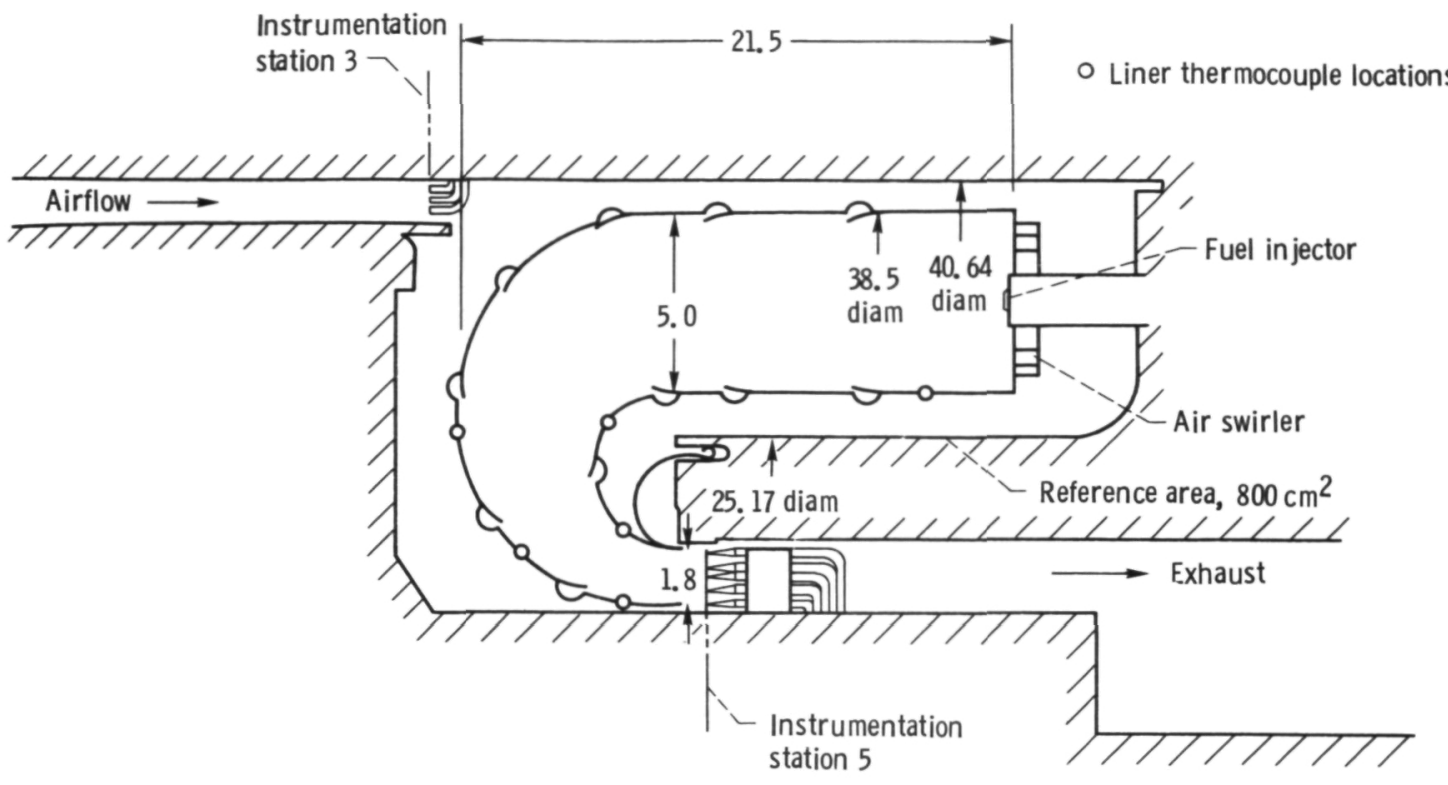

Combustor centerline

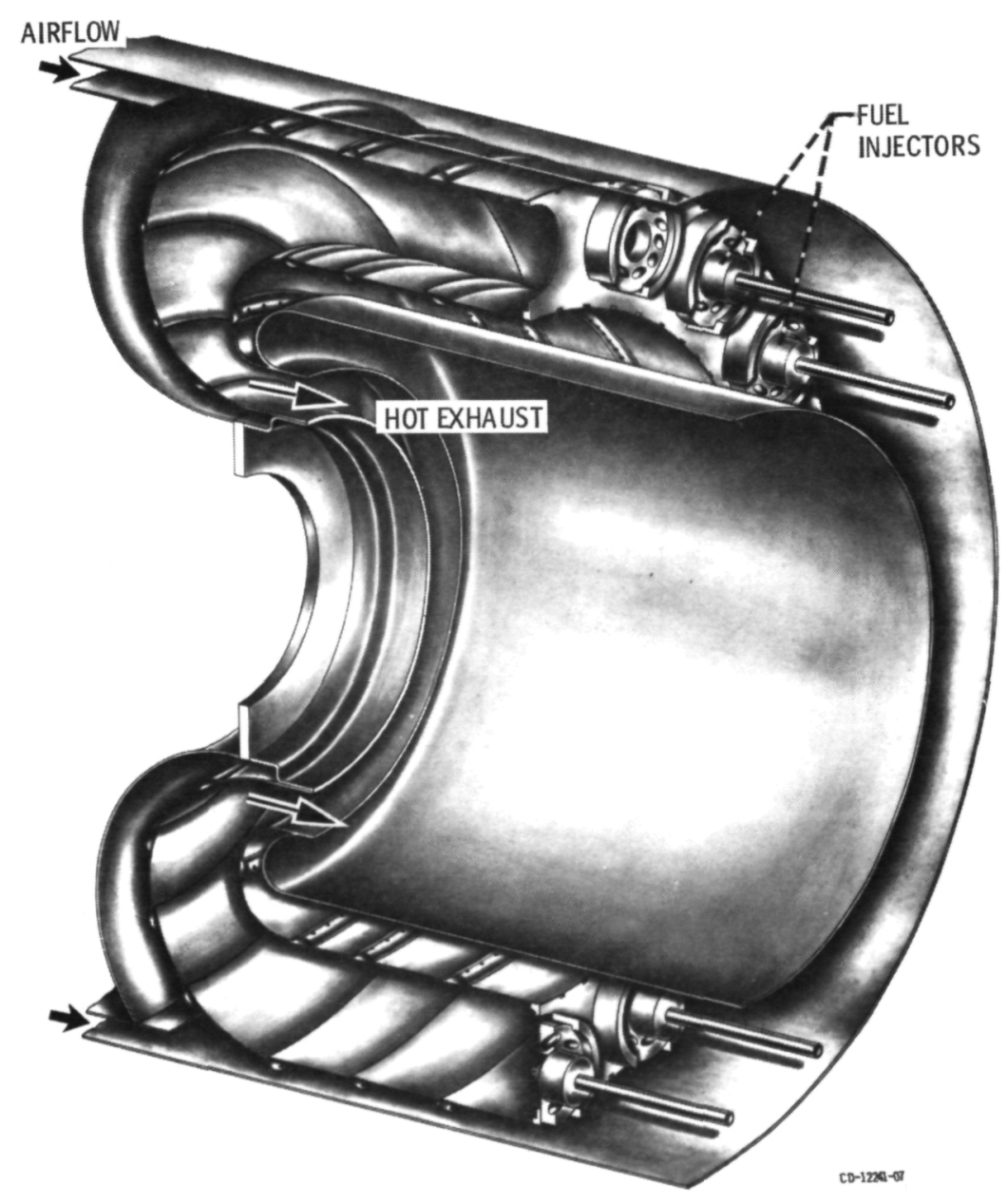

Figure 2. - Test combustor. All dimensions in centimeters. 


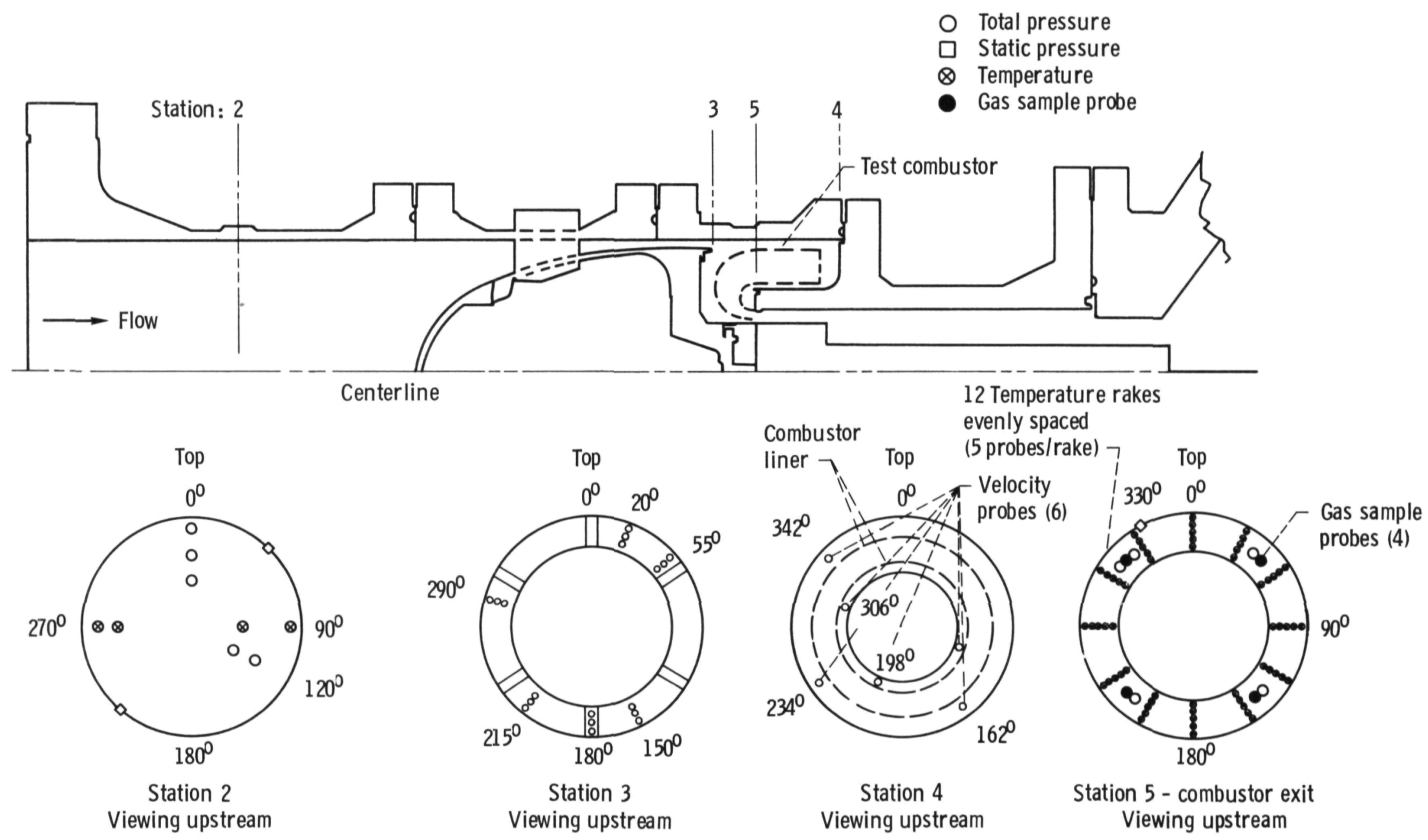

Figure 3. - Research instrumentation. 

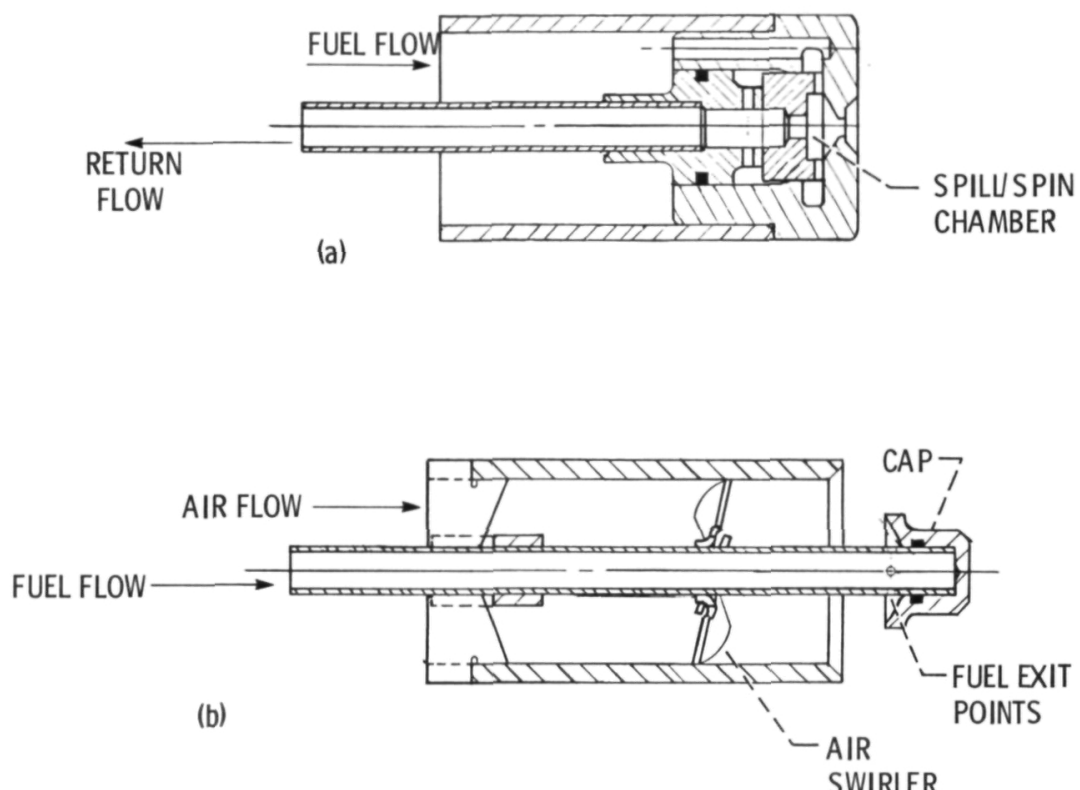

(a) Spill-flow.

(b) Splash cone.

Figure 4. - Fuel injector schematics 


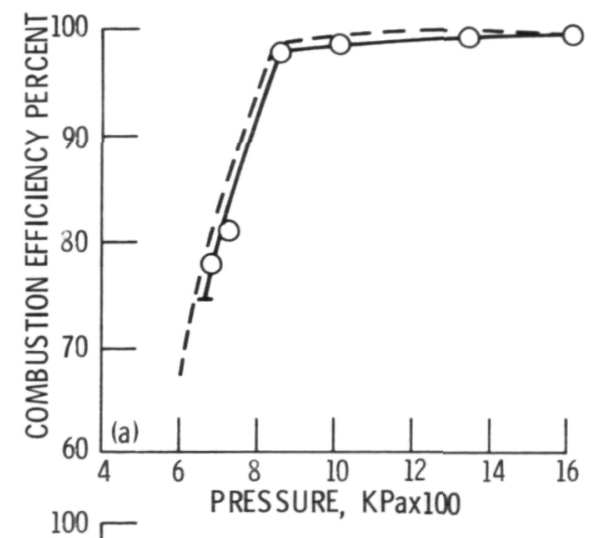

FUEL

ERBS
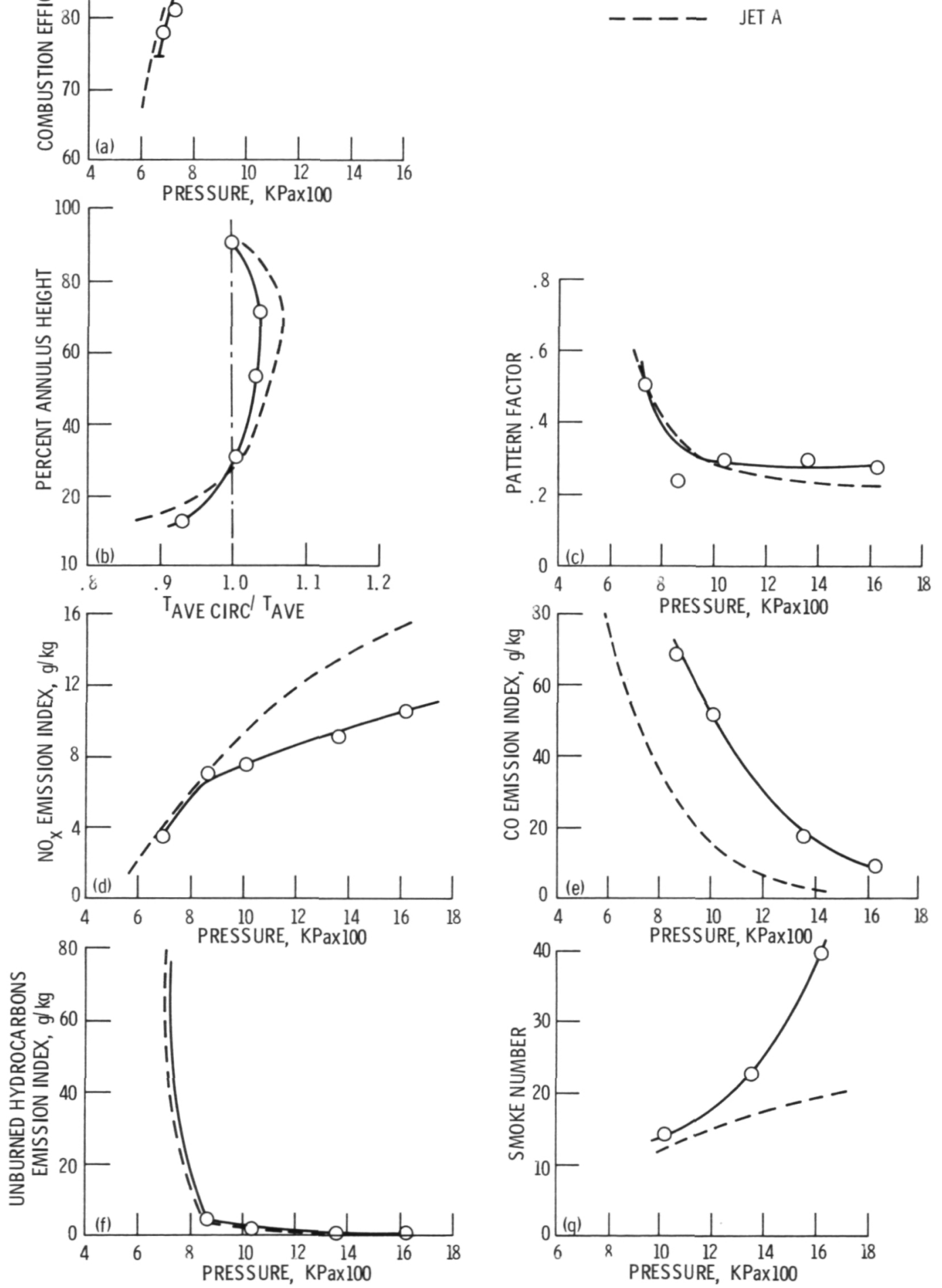

(a) Combustion efficiency.

(b) Outletradial average temperature profile for simulated sea level take off conditions.

(c) Pattern factor.

(d) $\mathrm{NO}_{x}$ emission index.

(e) CO emission index.

(f) Unburned hydrocarbons emission index.

(g) Smoke number.

Figure 5. - Performance of simplex fuel injectors in a reverse flow combustor burning ERBS fuel. Fuel air ratio, approximately 0.014 . 


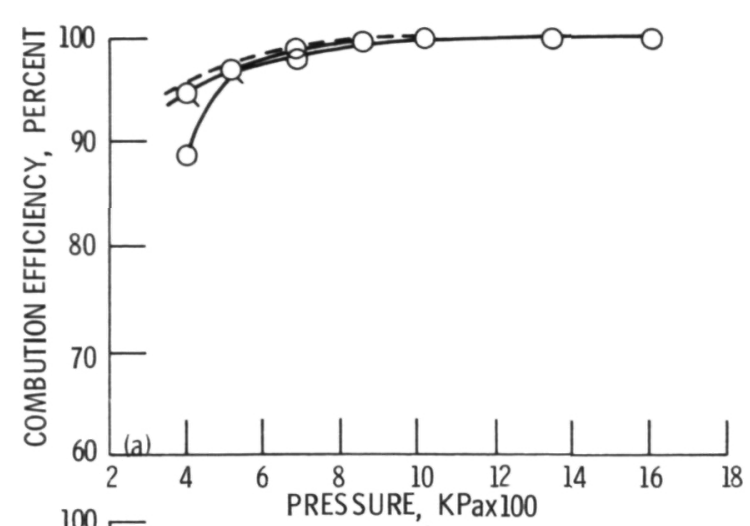

MODE OF

OPERATION

NO SPILL

Q SPILL

FUEL

ERBS
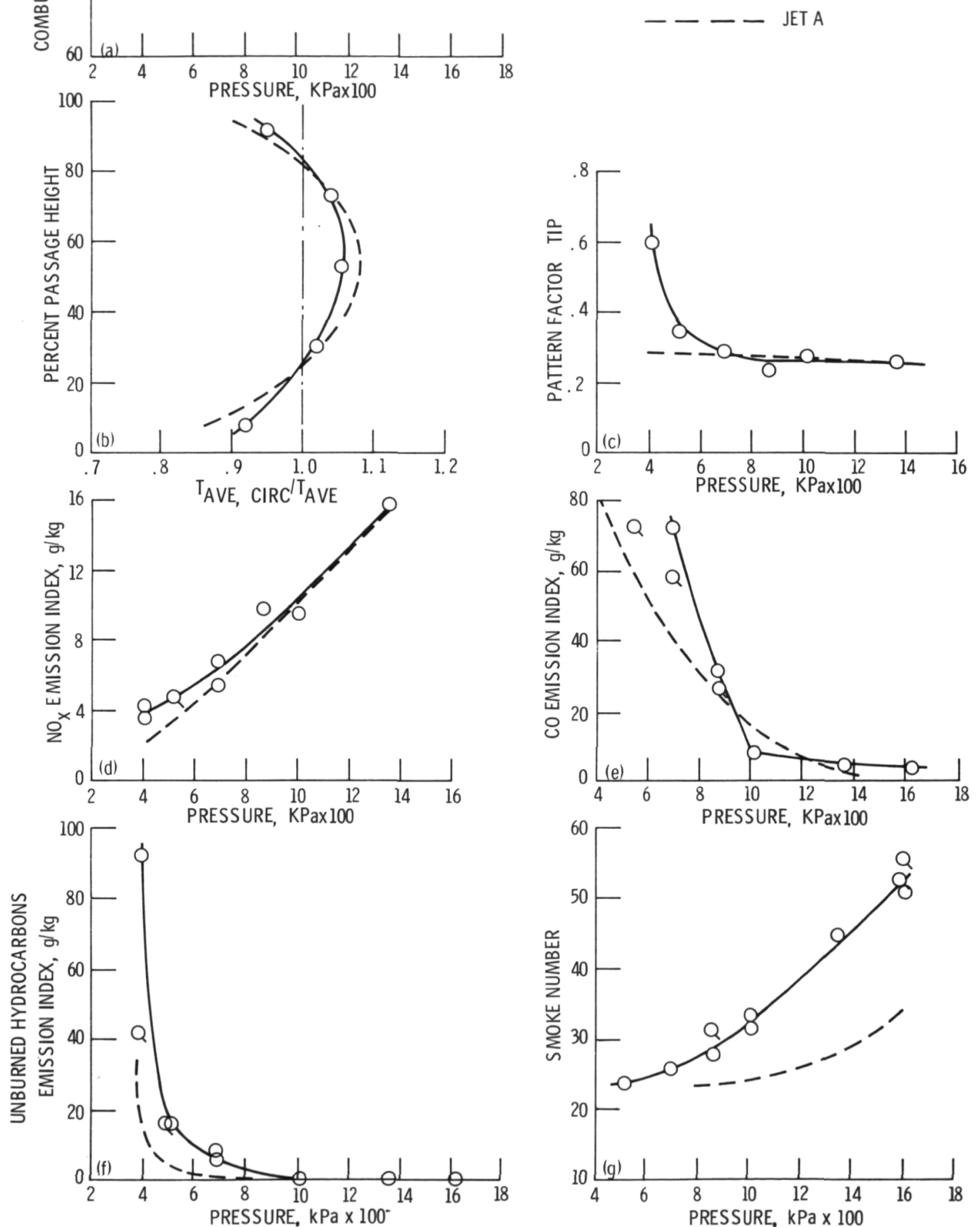

(a) Combustion efficiency.

(b) Average exit temperature radial profile.

(c) Pattern factor.

(d) $\mathrm{NO}_{x}$ emission index.

(e) CO emission index.

(f) Unburned hydrocarbons emission index.

(g) Smoke number.

Figure 6. - Performance of a spill return fuel injector with ERBS fuel. 

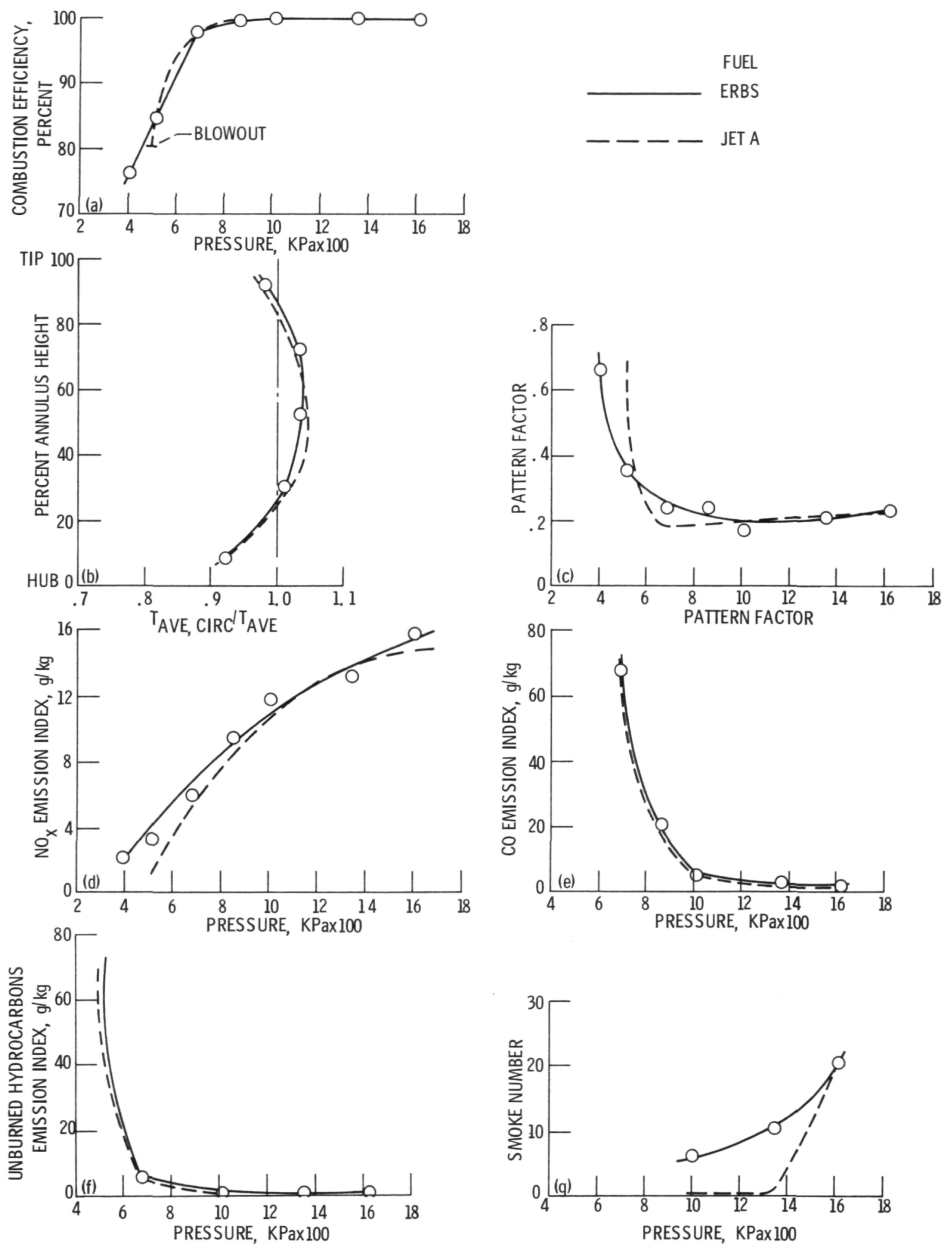

(a) Combustion efficiency.

(b) Average exit radial temperature profile at simulated sea level takeoff.

(c) Pattern factor.

(d) $\mathrm{NO}_{\mathrm{x}}$ emission index.

(e) CO emission index.

(f) Unburned hydrocarbons emission index.

(g) Smoke number.

Figure 7. - Performance of splash cone fuel injectors in a reverse flow combustor using ERBS fuel. 



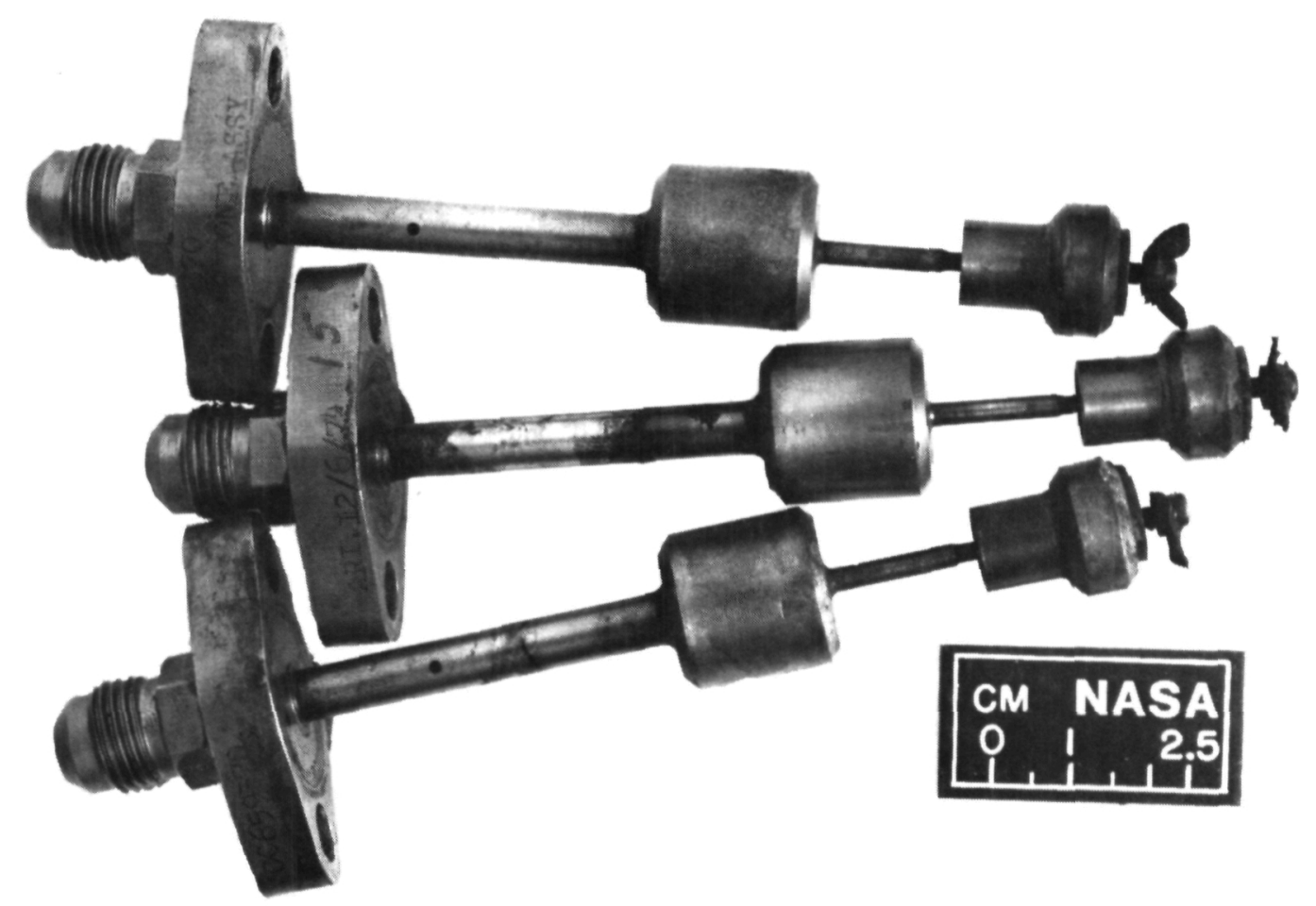

C-80-1968

Figure 9. - Carbon formation on splash cone injector tips with ERBS fuel. 


\begin{tabular}{|c|c|c|c|}
\hline $\begin{array}{l}\text { 1. Report No. NASA TM }-83013 \\
\text { AIAA }-83-0154\end{array}$ & 2. Government Accession No. & \multicolumn{2}{|c|}{ 3. Recipient's Catalog No. } \\
\hline \multirow{2}{*}{\multicolumn{2}{|c|}{$\begin{array}{l}\text { 4. Title and Subtitle } \\
\text { EFFECT OF BROAD PROPERTIES FUEL ON INJECTOR } \\
\text { PERFORMANCE IN A REVERSE FLOW COMBUSTOR }\end{array}$}} & \multicolumn{2}{|l|}{ 5. Report Date } \\
\hline & & \multicolumn{2}{|c|}{$\begin{array}{l}\text { 6. Performing Organization Code } \\
505-32-32\end{array}$} \\
\hline \multirow{2}{*}{\multicolumn{2}{|c|}{$\begin{array}{l}\text { 7. Author(s) } \\
\text { Stephen M. Riddlebaugh and Carl T. Norgren }\end{array}$}} & \multicolumn{2}{|c|}{$\begin{array}{l}\text { 8. Performing Organization Report No. } \\
\text { E-1448 }\end{array}$} \\
\hline & & \multicolumn{2}{|l|}{ 10. Work Unit No. } \\
\hline \multirow{2}{*}{\multicolumn{2}{|c|}{$\begin{array}{l}\text { 9. Performing Organization Name and Address } \\
\text { National Aeronautics and Space Administration } \\
\text { Lewis Research Center } \\
\text { Cleveland, Ohio } 44135\end{array}$}} & \multicolumn{2}{|c|}{ 11. Contract or Grant No. } \\
\hline & & \multirow{2}{*}{\multicolumn{2}{|c|}{$\begin{array}{l}\text { 13. Type of Report and Period Covered } \\
\text { Technical Memorandum }\end{array}$}} \\
\hline \multirow{2}{*}{\multicolumn{2}{|c|}{$\begin{array}{l}\text { 12. Sponsoring Agency Name and Address } \\
\text { National Aeronautics and Space Administration } \\
\text { Washington, D. C. } 20546\end{array}$}} & & \\
\hline & & \multicolumn{2}{|c|}{ 14. Sponsoring Agency Code } \\
\hline \multicolumn{4}{|c|}{$\begin{array}{l}\text { 15. Supplementary Notes } \\
\text { Prepared for the Twenty-First Aerospace Sciences Conference sponsored by the American } \\
\text { Institute of Aeronautics and Astronautics, Reno, Nevada, January } 10-13,1983 \text {. }\end{array}$} \\
\hline \multicolumn{4}{|c|}{$\begin{array}{l}\text { 16. Abstract } \\
\text { The effect of fuel type on the performance of various fuel injectors was investigated in a } \\
\text { reverse flow combustor. Combustor performance and emissions are documented for simplex } \\
\text { pressure-atomizing, spill flow, and airblast fuel injectors using a broad properties fuel and } \\
\text { compared with performance using Jet A fuel. Test conditions simulated a range of flight } \\
\text { conditions including sea-level take-off, low and high altitude cruise, as well as a parametric } \\
\text { evaluation of the effect of increased combustor loading. The baseline simplex injector pro- } \\
\text { duced higher emission levels with corresponding lower combustion efficiency with the broad } \\
\text { properties fuel. There was little or no loss in performance by the two advanced concept } \\
\text { injectors with the broad properties fuel. The airblast injector proved to be especially insen- } \\
\text { sitive to fuel type. }\end{array}$} \\
\hline \multicolumn{2}{|l|}{$\begin{array}{l}\text { 17. Key Words (Suggested by Author(s)) } \\
\text { Fuel injectors } \\
\text { Broad spec fuels } \\
\text { Broad properties fuels } \\
\text { Reverse flow combustors }\end{array}$} & \multicolumn{2}{|c|}{$\begin{array}{l}\text { 18. Distribution Statement } \\
\text { Unclassified - unlimited } \\
\text { STAR Category } 07\end{array}$} \\
\hline $\begin{array}{l}\text { 19. Security Classif. (of this report) } \\
\text { Unclassified }\end{array}$ & $\begin{array}{l}\text { 20. Security Classif. (of this page) } \\
\text { Unclassified }\end{array}$ & 21. No. of Pages & 22. Price ${ }^{*}$ \\
\hline
\end{tabular}

${ }^{*}$ For sale by the National Technical Information Service, Springfield, Virginia 22161 
National Aeronautics and Space Administration

Washington, D.C.

20546

Ofticial Business

Penaliy for Private Use, $\$ 300$
SPECIAL FOURTH CLASS MAIL BOOK

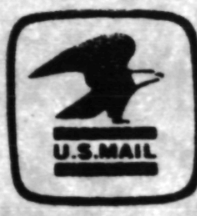

Postage and Fees Pand National Aeronautics and Space Administration NASA.451 